\title{
Sedimentology and ichnology of the mid-Cretaceous succession of the Ouled Nail Mounts (Eastern Saharan Atlas, Algeria)
}

\author{
Mohammed Nadir Naimi and Amine Cherif \\ Université Kasdi Merbah, Laboratoire de Géologie du Sahara, Ghardaïa Road, Ouargla, 30000, Algeria; (naimi.mohamed_nadir@univ-ouargla.dz \\ (Mohammed Nadir Naimi), acherif11@gmail.com (Amine Cherif))
}

doi: $10.4154 / g c .2021 .15$

\section{Article history:}

Manuscript received December 15, 2020 Revised manuscript accepted May 31, 2021 Available online October 15, 2021
Keywords: Trace fossils, Transgression, Albian - Cenomanian, Ouled Nail Mounts, Algeria

\begin{abstract}
Shallow marine deposits characterize the upper Albian - lower Cenomanian deposits of Northern Algeria. In Djebel Azzeddine (Ouled Nail Mounts), the corresponding sediments have been subdivided into three distinctive units $A$ to $C$. The first discovered ammonite fauna from the Bou Saada area allowed the attribution of a part of the mid-Cretaceous post-Continental Intercalaire deposits to the upper Albian. The ammonite-bearing level indicates a maximum flooding surface and could be correlated with similar levels from Northern Algeria. The studied succession is characterized by a low ichnodiversity containing eight ichnotaxa with abundant Thalassinoides, common Skolithos, and rare Gyrolithes, Oichnus, Planolites and cf. Tisoa. This ichnoassemblage is dominated by domichnion, fodinichnion and praedichnion trace fossils, and is attributed to the Skolithos and Glossifungites ichnofacies. These traces are produced mainly by decapod crustaceans, polychaetes and naticid gastropods. The sedimentological and ichnological data suggest shoreface to backshore environments with mixed tide/storm energy, and long subaerial exposures indicated by Lofer cyclothems in the lowermost part and dinosaur footprints in the upper part of the section.
\end{abstract}

\section{INTRODUCTION}

The Cretaceous deposits are widely distributed in the Algerian Saharan Atlas. In the last few years, several sedimentological, bio-lithostratigraphic and palaeontological studies were focused on the mid-Cretaceous strata of the western (Ksour Mounts) and central Saharan Atlas (Djebel Amour Mounts) (MEBARKI et al., 2016; BENYOUCEF et al., 2017; FERRÉ et al., 2017; MENNAD et al., 2020; SALHI et al., 2020; ÖZER \& BENYOUCEF, 2021). In the Ouled Nail Mounts (eastern part of the Saharan Atlas), the corresponding deposits are represented by a succession made of marly-limestone/dolostone alternations which display a rich macrofauna (bivalves, gastropods, ammonites), as well as trace fossils. The best exposures of this interval crop out in the Djebel Azzeddine, Djebel Amrane and Djebel Tsegna, and were first extensively explored by BROSSARD (1866), PÉRON (1883) and RITTER (1902). The studied interval has been mapped and investigated since the late mid 20th century (EMBERGER, 1960; GUIRAUD, 1973; HERKAT, 1999). Unfortunately, with the exception of the previously cited works, no comprehensive revision of the upper Albian-lower Cenomanian succession has been carried out in recent years. The late Albian (Vraconnian) - lower Cenomanian interval is thereby considered as an important eustatic event, corresponding to the global and greatest mid-Cretaceous transgression (HANCOCK \& KAUFFMAN, 1979; AMÉDRO, 2008).

This paper aims to provide the first sedimentological and ichnological study of the upper-Albian transgressive marine deposits exposed in Djebel Azzeddine (Ouled Nail Mounts). Our contribution provides the first ammonite-bearing level, ichnotaxa inventory, detailed facies analysis and new dinosaur footprint record that facilitates identification of the depositional environment and the palaeobiogeography in the Saharan Atlas during the midCretaceous.

\section{GEOLOGICAL SETTING}

The Algerian Atlasic system consists of the Saharan Atlas to the west, and the Aures, Nementcha, Negrine and Tebessa Mountains to the east (e.g., DJEBBAR, 2000). Their equivalents are the High and Middle Atlas in Morocco, and the Tunisian Atlas in Tunisia, forming, together with the Tell-Rif system to the North, the Atlas Mountains belts sensu lato of northwestern Africa (HALAMSKI $\&$ CHERIF, 2017), considered as part of the west Mediterranean alpine system (Fig. 1A).

The Ouled Nail Mounts represent the eastern part of the Saharan Atlas (Fig. 1B), which corresponds to an intracratonic autochthonous chain located in northern Algeria, belonging to the Atlasic system (DJEBBAR, 2000; NAIMI \& CHERIF, 2021a; NAIMI et al., 2021a). The Algerian Saharan Atlas extends SWNE over about $650 \mathrm{~km}$ in length and 90 to $140 \mathrm{~km}$ wide between the Moroccan High-Atlas and the Zibane Mountains (or Biskra promontory) (GUIRAUD, 1973). This chain was developed in a subsiding intra-plate asymmetric basin, in existence since the Triassic, located between two stable domains, the Oran Meseta (High Plateaus) in the North, and the Saharan Platform in the South, from which it is respectively isolated, by the South Mesetan and the South Atlasic Faults (KAZI-TANI, 1986).

The stratigraphic series (Fig. 1C) of the study area (the northeastern part of the Ouled Nail Mounts) begins with Triassic strata cropping out in diapirs (Kerdada and Ain Ograb), represented by purplish clays, gypsum, dolostones and doleritic ophites. The Triassic rocks are overlain by a $6000 \mathrm{~m}$-thick Cretaceous (Valanginian to Maastrichtian) succession. The Cenozoic (Paleogene to Quaternary) continental deposits unconformably overlie the Mesozoic sediments (EMBERGER, 1960).

The mid-Cretaceous sedimentary succession cropping out in the investigated area is characterized by lower Albian continental sandstones of the Continental Intercalaire, rich in the re- 

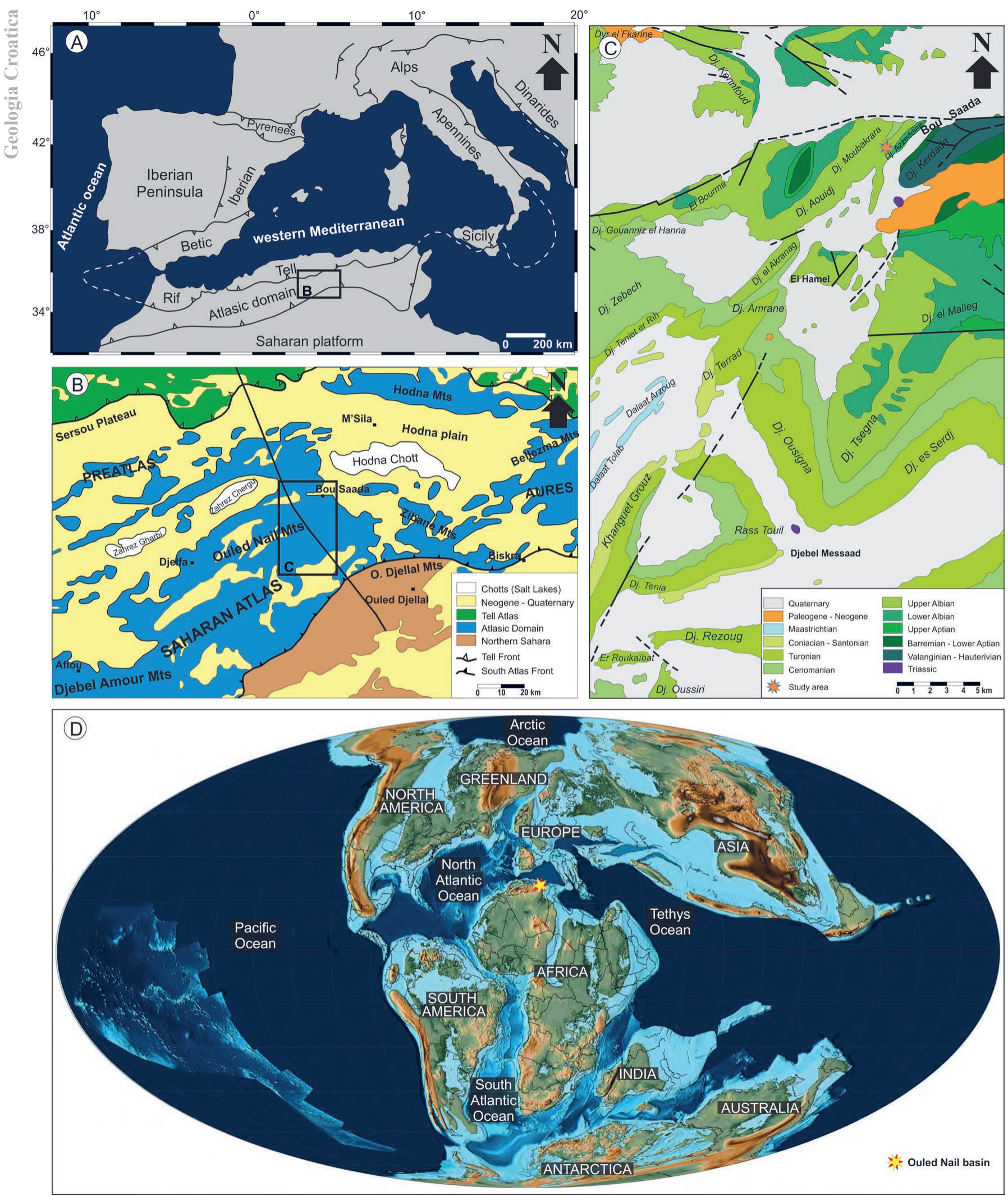

Figure 1. Location map of the study area. (A) Location of central Algeria in the western Mediterranean; (B) The main structural domains of central Algeria; (C) Simplified geological map of the Bou Saada area (modified after the geological map of Bou Saada 1/200.000); (D) Late Albian global palaeogeography and location of the Ouled Nail basin (map after SCOTESE, 2013).

mains of vegetation (EMBERGER, 1960), overlain by shallow marine carbonate platform deposits. The lower part (300-400 m) of this sequence is dated as upper Albian, consisting of marlydolostone alternations rich in fragments of oyster shells. The palaeontological content of these facies suggests a very shallow marine environment under rough-water conditions (NAIMI et al., 2021b).

The lower part of the overlying 460-735 m-thick Cenomanian strata is characterized by shallow-water marlstone-limestones. They are similar to the underlying upper Albian deposits, 


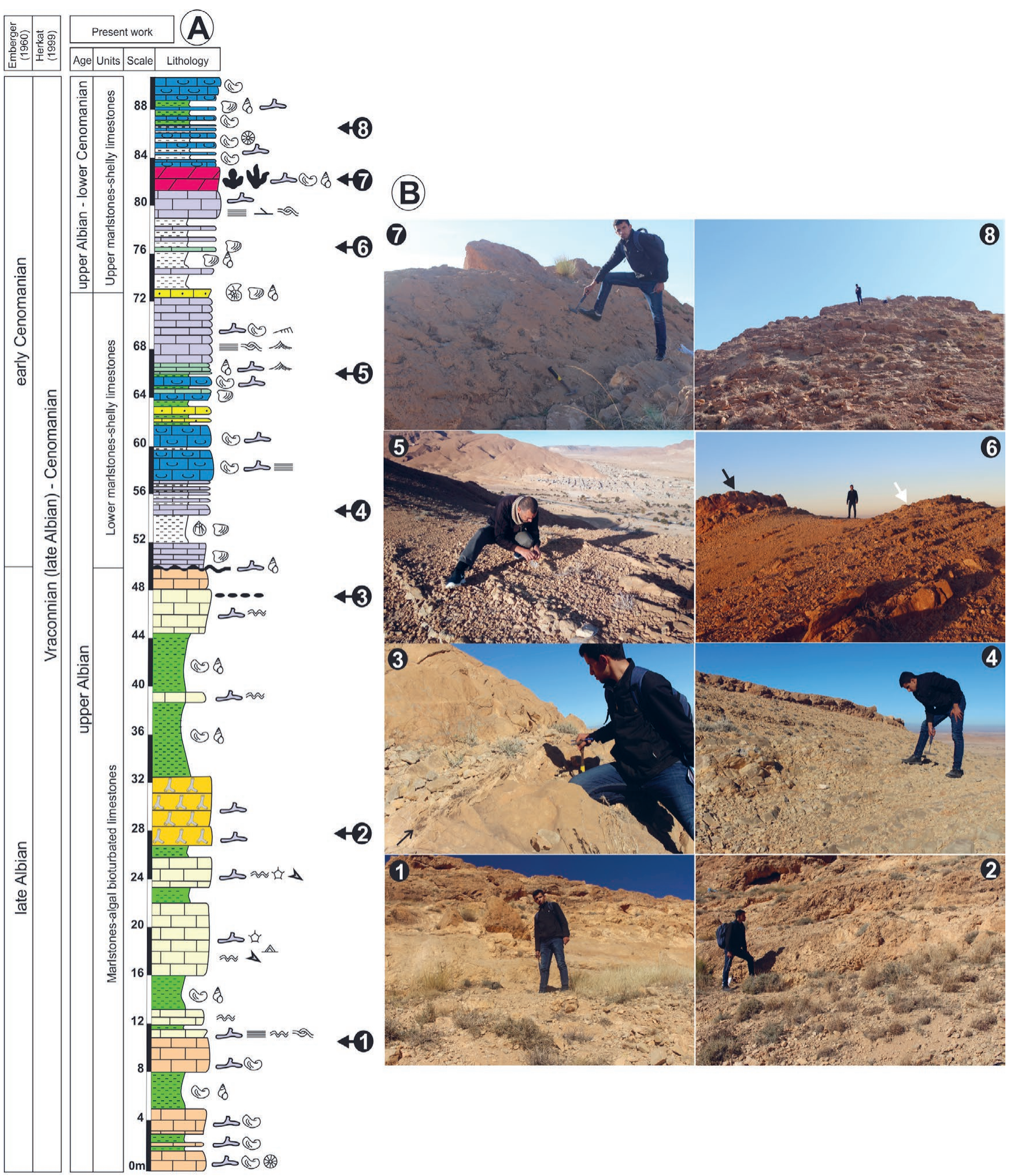

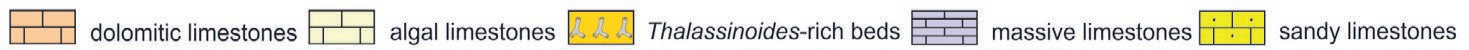
니 shelly limestones $\square$ molluscan-rich beds $\lambda$ cross laminations 2 hummocky cross stratifications $-\pi$ linguoid ripple marks wave ripples $\Delta$ gypsum crystals 工f dessication cracks $\mathbb{A}$ tepee $\approx$ algal laminations $\sim m$ hardground $\cdots$ chert level $\Omega$ bioturbation echinoids ornithopod footprints $\psi$ theropod footprints ammonites 8 gastropods (20) bivalves (it) oysters brachiopods
}

Figure 2. The main lithostratigraphic characteristics of the upper Albian - lower Cenomanian of Djebel Azzeddine. (A) Lithostratigraphic column of the Djebel Azzeddine section; (B) Field photography of the studied succession: 1, dolomitic limestones of the lowermost part of the section; 2 , Thalassinoides-rich beds; 3 , algal limestones of the uppermost part of Unit A (black arrow shows the chert level); 4, micritic limestones of Unit B; 5, gastropod-rich limestones; 6, the lowermost part of Unit C (white arrow indicate ammonites-bearing limestones; black arrow indicate dinosaur tracks-bearing dolostones); 7 , dinosaur tracks-bearing surface; 8, marls-shelly limestones alternation from the uppermost part of the section. 
rich in oysters and echinoderms, and overlain by lagoonal marlstone-dolostone alternations and thick gypsum beds with subordinate limestone interlayers rich in foraminifera (EMBERGER, 1960). The uppermost part of the Cenomanian beds consists of massive mudstones, nodular and bioclastic limestones and black shales (GROSHENY et al., 2008).

\section{MATERIAL AND METHODS}

Two field expeditions (December 2019 and March 2020) were conducted. During these missions the mid-Cretaceous succession cropping out in Djebel Azzeddine near the city of Bou Saada was sampled and described bed-by-bed for lithological changes, colour, composition, geometry, sedimentary structures and palaeontological content. The fossils (bivalves, gastropods, ammonites and brachiopods) as well as trace fossils were photographed in situ, collected and stored in the Géologie du Sahara laboratory (Kasdi Merbah University) to be identified and investigated for their palaeoenvironmental interest.

A new dinosaur tracksite was discovered in the studied succession. However, further studies on these footprints are required.

\section{LITHOSTRATIGRAPHIC FRAMEWORK AND PALAEOENVIRONMENT}

The Upper Albian - Lower Cenomanian deposits of Djebel Azzeddine were framed as Vraconnian - Cenomanian, corre- sponding to a megasequence, divided into two fourth-order sequences (HERKAT, 1999). In the present work, the studied interval has been subdivided into three informal units (Fig. 2).

\subsection{Unit A: Marlstone-algal bioturbated limestones unit (upper Albian)}

This $52 \mathrm{~m}$-thick unit constitutes the base of the marine mid-Cretaceous deposits outcropping near the city of Bou Saada. Its lower limit has been hidden due to recent urbanization. EMBERGER (1960) indicates that Djebel Azzeddine marine carbonates overlie Albian sandstones of the Continental Intercalaire. The dominant stacking pattern of this unit is represented by an obvious rhythmicity expressed by discrete bed packages $(0.6-6 \mathrm{~m}$ thick $)$ of limestones and dolomitic limestones intercalated with greenish to grayish soft, occasionally foliated, fossiliferous marlstones $(0.6-3 \mathrm{~m})$ (Fig. 2). The limestones are hard, highly burrowed with large Thalassinoides isp. (Fig. 7A) and organized in shallowingupwards wackestone to packstone. They are massive, sub-nodular (Fig. 3A), rarely laminated, yellow, light to dark brown in colour when weathered, white to light gray in cross-section and mostly with sharp erosive bases. The fossil components are dominated by oysters, gastropods and echinoids. These dolomitic limestones show a red loferitic breccia, mud cracks, parallel laminations, micro-HCS (hummocky-cross stratifications), stromatolitic laminae, silex layers, paleosol, teepee structures and shrinkage pores (Fig. 3B, D and E). The upper contact of this unit
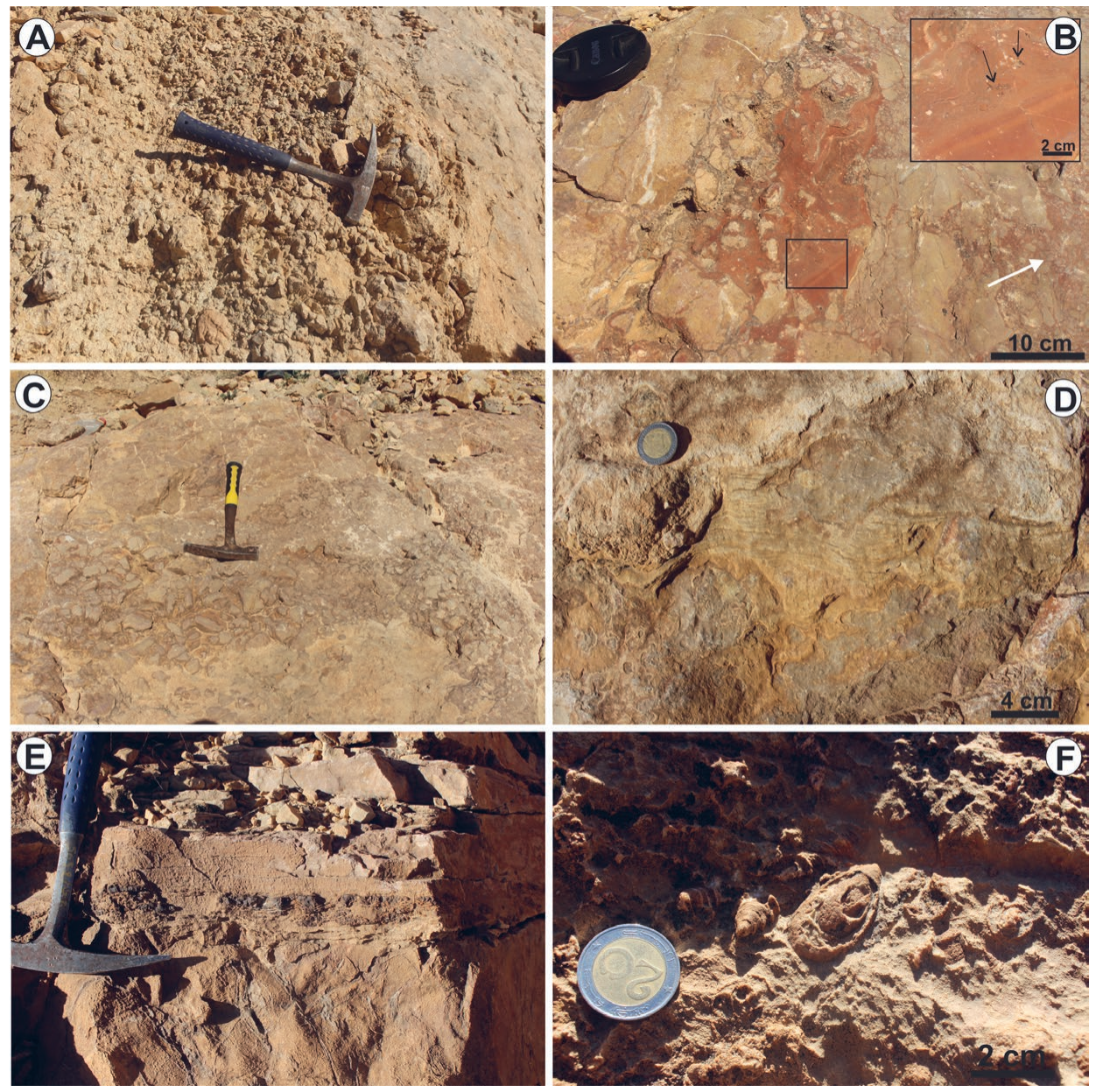

Figure 3. Field photographs of Unit A. (A) Pseudo-nodular limestones; (B) Intertidal to supratidal limestones with algal laminae, paleosol, shrinkage pores (black arrows), and loferitic breccia (white arrow); (C) Subtidal limestones with in-situ slumped breccia; (D) Stromatolitic limestone; (E) Dolomitic limestone showing algal laminae including chert nodules; (F) Top surface of dolomitic limestone showing hardground with abundant Acteonella delgadoi. 
corresponds to a hardground with oxidized dolo-mudstones characterized by condensed gastropod levels dominated by the species Actnonella delgadoi, as well as vertical borings (Fig. 3F).

\subsection{Unit B: Lower marlstone-shelly limestone unit (upper Albian)}

This $22.5 \mathrm{~m}$-thick unit comprises white and green marls $(0.2-$ $2.5 \mathrm{~m}$ ) alternating with grayish to yellowish massive, shelly and sandy limestones. The limestone beds are 0.05 to $2.5 \mathrm{~m}$ thick, broadly pseudo-nodular to nodular, bioturbated, channelized, white to dark gray weathering coloured, gray to yellowish in cross-section, showing noteworthy densely packed thin bioclasts of benthic fauna, organized in packstone to grainstone textures (Fig. 4A). The middle part of this unit exhibits many subordinate shell beds ( $0.2-2.5 \mathrm{~m}$ thick), thinning upwards, amalgamated and wave rippled, showing a rapid transition into an overlying marly lithofacies, namely: Cucullaea-rich limestones corresponding to bioturbated limestone, composed of monotaxic bivalves (Cucullaea sp.) (Fig. 4B), and polytaxic gastropod-rich limestones with fragmented and randomly oriented shells (Fig. 4C). A scarce brachiopod fauna is also present.

Internally, the limestone beds of this unit contain small scale hummocky-cross stratifications, lenticular, flaser to wavy bedding, internal mud drapes, tidal rhythmites, unidirectional, linguoid, wavy ripple marks and mega ripples (Fig. 4D-E). The ichnotaxa of this unit are represented by Gyrolithes isp. (Fig. 6A), Oichnus isp. (Fig. 6B) and cf. Tisoa siphonalis (Fig. 7E).
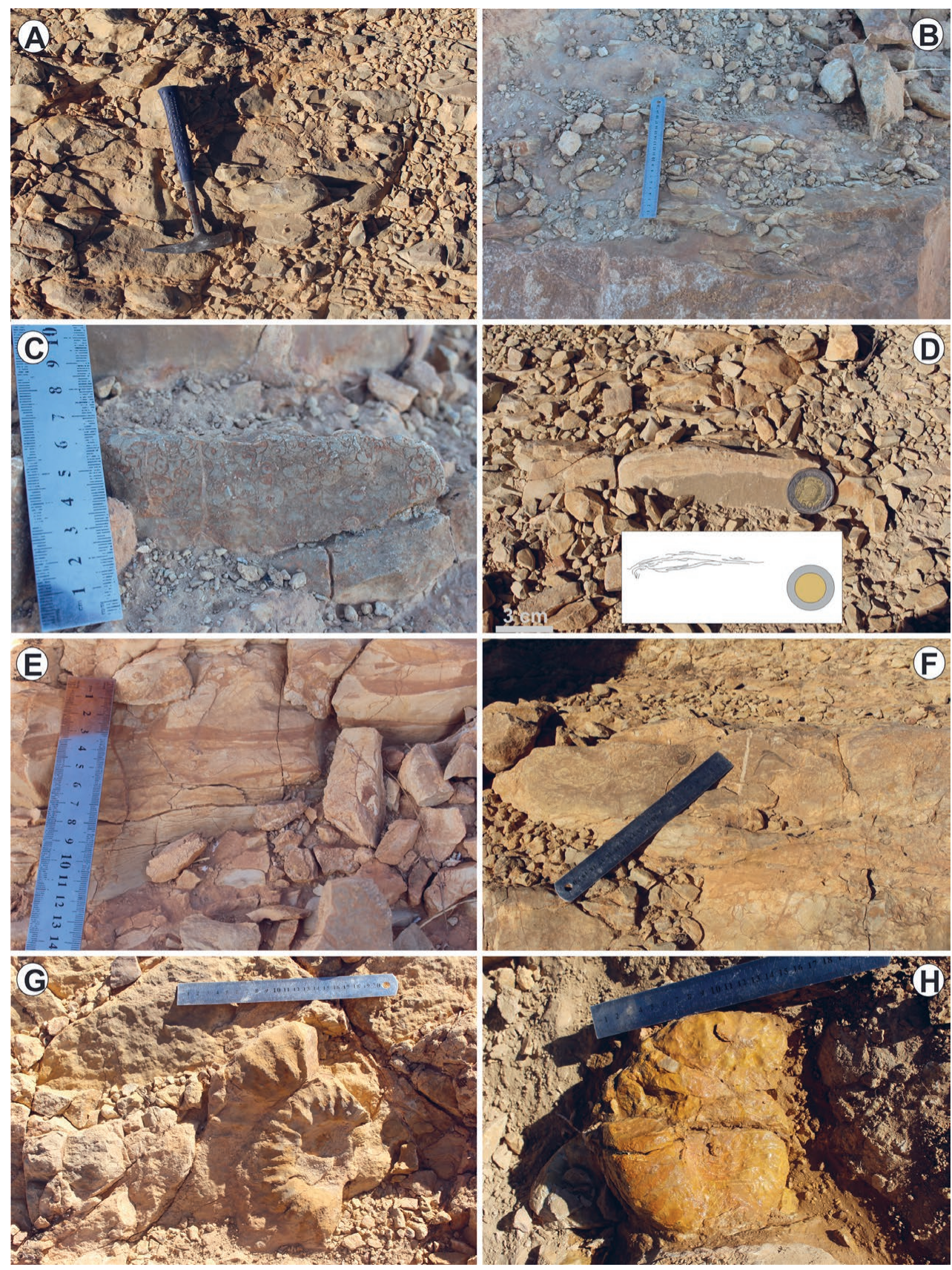

Figure 4. Field photographs of Unit B. (A) Micritic limestone bed; (B) Cucullaea-rich limestones; (C) Gastropod-rich limestones, with sharp erosive base and ripplemark in top surface; (D) Small-scale hummocky-cross stratification in fine limestone bed at the top of the unit, with light micritic laminae and dark sandy-micritic laminae; (E) Tidal rhythmites from the top of the unit; (F) Limestone bed with robust bioclasts of oysters and wavy rippled upper surface; (G-H) Large size Mortoniceracidae of the ammonites-bearing bed. 
The uppermost part of this unit is representedby a concentration of large-sized ammonites Mortoniceras sp. and Pervinquieria sp., arranged in single post-mortem disposition (Fig. $4 \mathrm{G}-\mathrm{H}$ ), and small fragments of Engonoceras sp. which co-occur with bivalves and gastropods.

\subsection{Unit C: Upper marlstone-shelly limestone unit (upper Albian - lower Cenomanian)}

The lower part of this $18 \mathrm{~m}$-thick unit is composed of an alternation of white marls $(2-3 \mathrm{~m})$ and whitish massive limestones with sporadic, thin, bivalve shell beds of Cucullaea sp. These limestone beds are hard, display yellow-red sandy inclined burrows as Planolites isp. (Fig. 6C), hummocky-cross stratifications (HCS), swaley-cross stratifications (SCS) and parallel and cross laminations (Fig. 5A-B).

The $2-3 \mathrm{~m}$-thick dolomite in the middle part of this unit is characterized by dinosaur footprints (Figs. 8 and 9) associated with vertical burrows attributed to Skolithos (Fig. 6D), as well as a rich assemblage of worn and recrystallized molds of bivalves and gastropods. The uppermost part of the studied succession consists of regular alternations of light green to white soft marls (Fig. 5E-F) and mollusk rich limestones, composed of abundant disarticulated and fragmented (Fig. 5C) or whole mollusk shells including bivalves and gastropods (Fig. 5D).

\subsection{Facies analysis}

On the basis of sedimentological and palaeontological characteristics such as lithology, sedimentary structures, fossils and/or trace fossils, bed thickness and taphonomy of shell beds, fifteen distinctive sedimentary facies types (FT1 to FT15) have been identified, described, interpreted and presented in Table 1 and Figures 3-5.

\subsection{Age of the succession}

Despite the extension of the mid-Cretaceous succession of the Ouled Nail Mounts, no detailed bio- and lithostratigraphic investigations have been previously carried out on these deposits. EMBERGER (1960), based only on lithological criteria, such as the occurrence of rich oyster shell fragment-limestones, assigned a latest Albian (Vraconnian) and early Cenomanian age to the midCretaceous marine sediments of the Djebel Azzeddine section. Furthermore, HERKAT (1999) assigned the same deposits to a whole Vraconnian-Cenomanian mega-sequence encompassing three successive sequences.

Our new findings indicate a late Albian-lower Cenomanian age for the mid-Cretaceous deposits of the Ouled Nail Mounts. No biostratigraphic fossils have been recorded in the lowermost part of the analyzed succession. The last bed of the first unit contains a condensed gastropod shell-bearing level of Acteonella
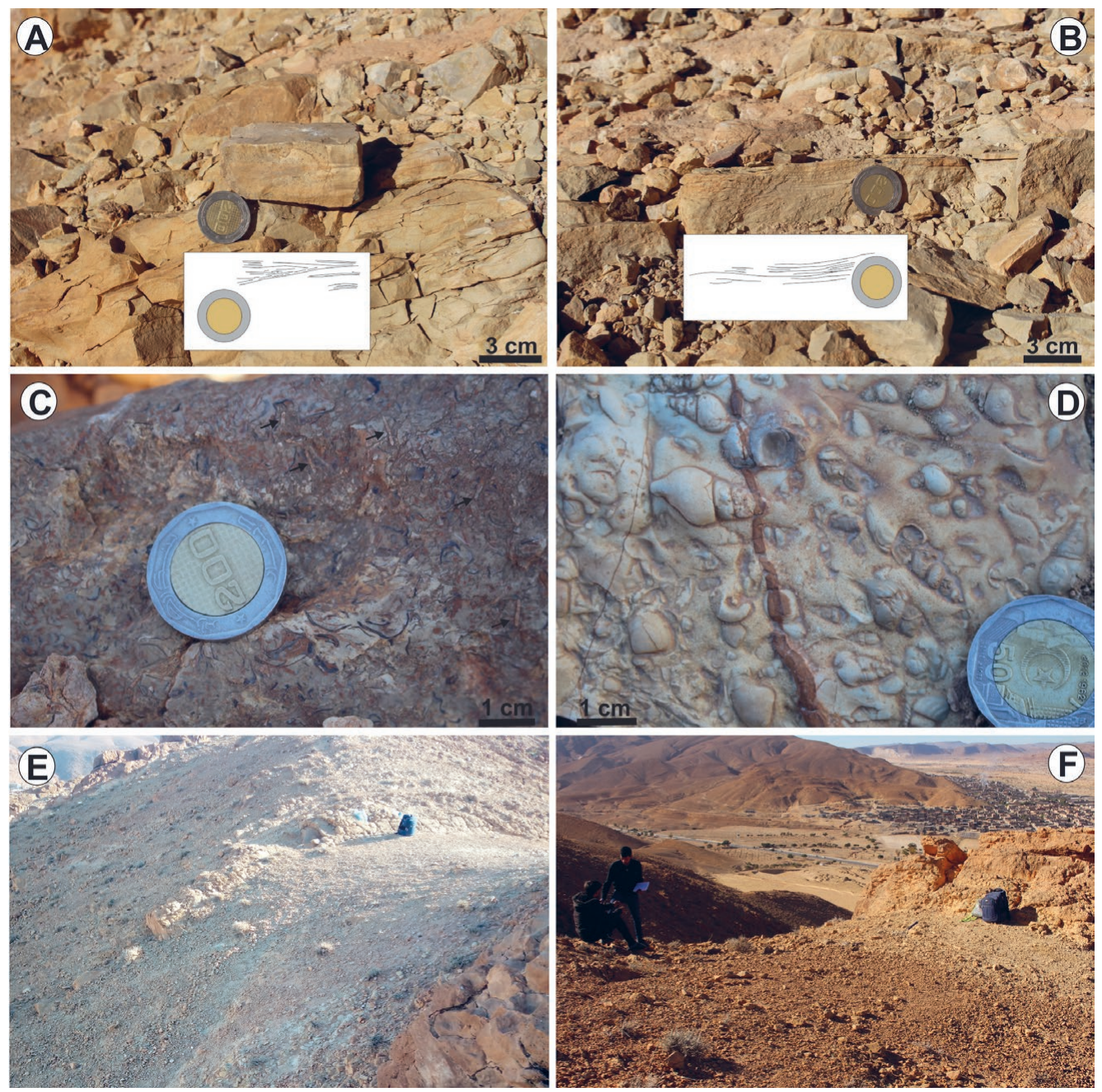

Figure 5. Field photographs of Unit C. (A) Limestone bed with low-angle cross lamination; (B) Limestone bed showing hummocky cross-stratification (HCS) and swaley cross-stratification (SCS); (C) Oyster-rich bioclastic limestone (black arrows indicate echinoid spines); (D) Limestone bed rich in gastropod and pectinid shells; (E) Greenish marls interlayered with limestone beds; (F) Uppermost part of the succession showing rhythmic whitish marls-dolomitic limestones alternations. 


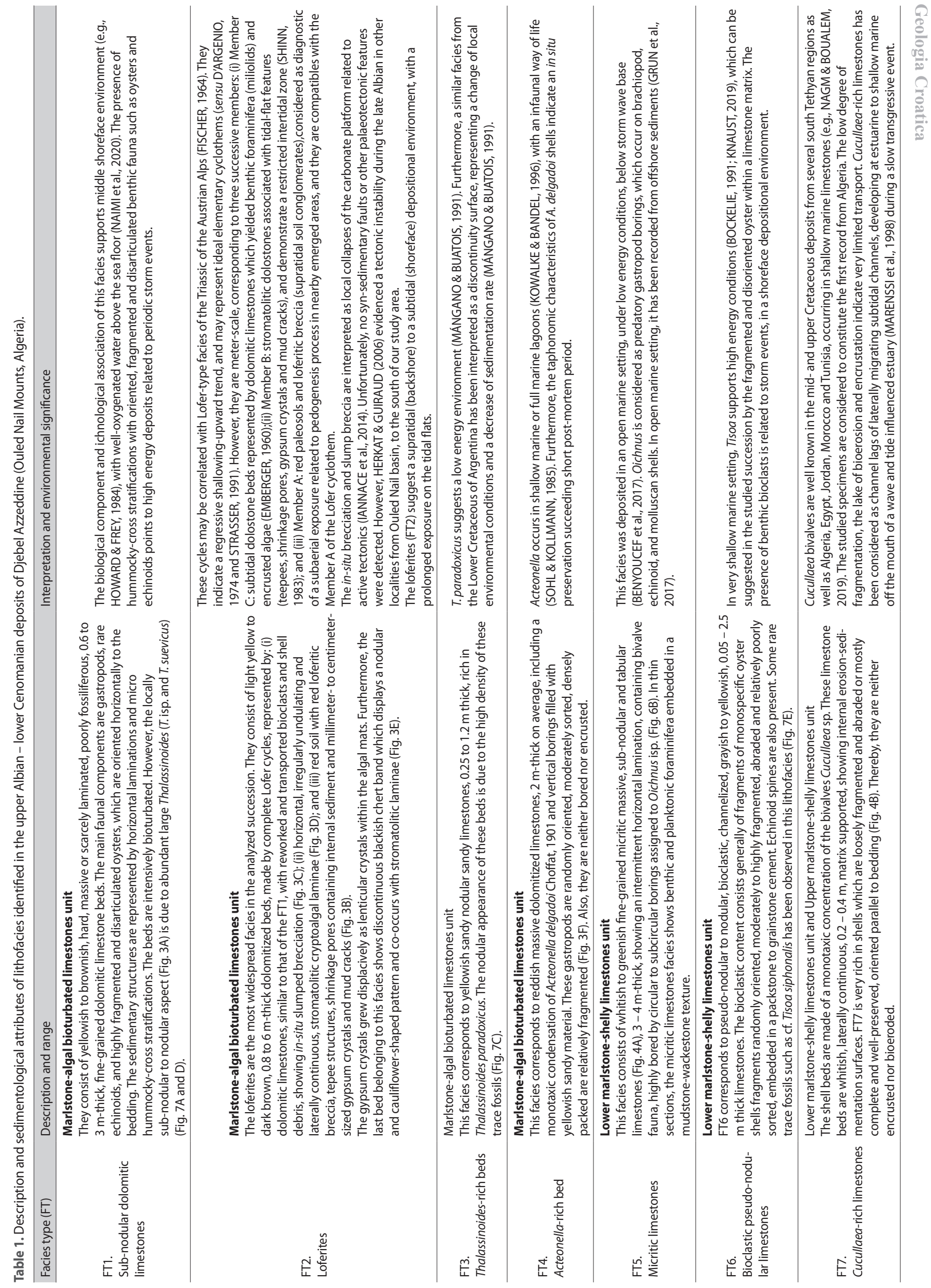


气

壳

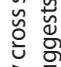

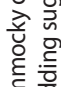

흥ㅎㅁ

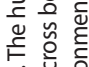

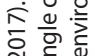

占产 。

政

둬웜

过

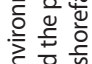

这 둔

는 트을

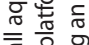

岛 웜

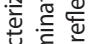

肎 응

ডับ ธ

芒

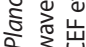

言

造

势

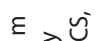

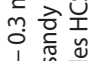

가에

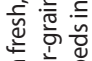

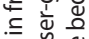

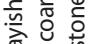

후원

흥 흥

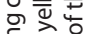

竧委

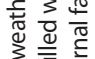

空

艺旁

荇光式.

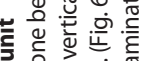

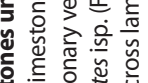

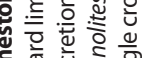

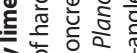

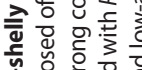

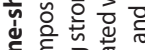

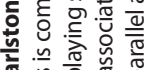

है

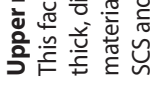

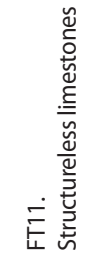

듣 氙

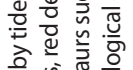

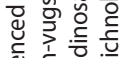

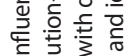

究产产

हैㄴㅎㅇㅎㅇ응

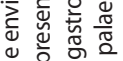

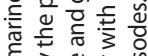

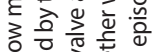

은

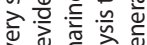

는

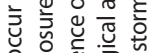

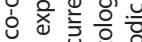

范

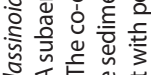

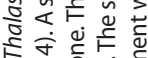

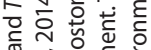

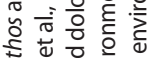

产岃. 충

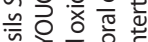

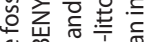

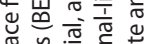

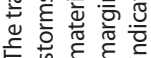

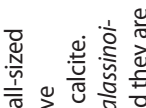

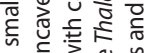

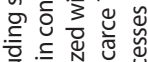

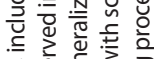

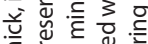

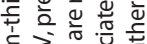

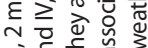

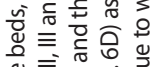

논

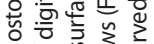

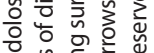

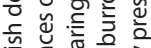

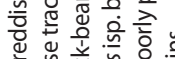

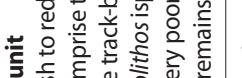

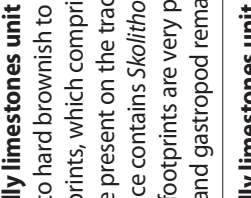

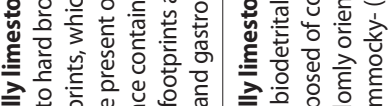

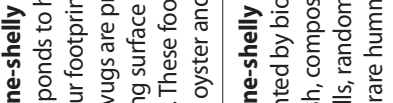

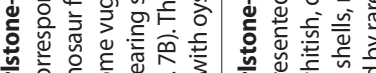

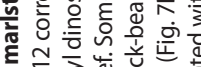

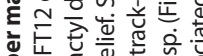

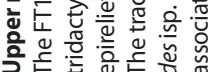

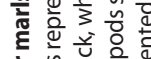

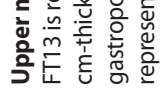

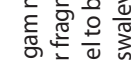

䨌衣

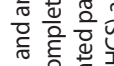
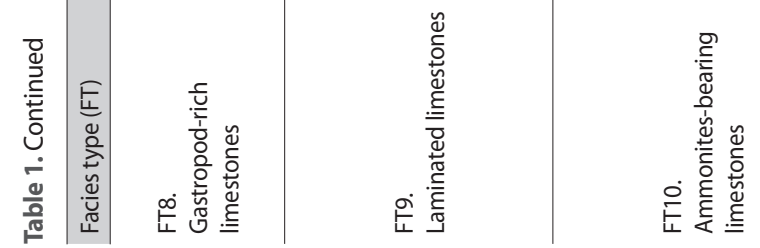

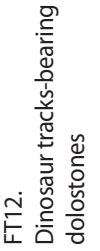

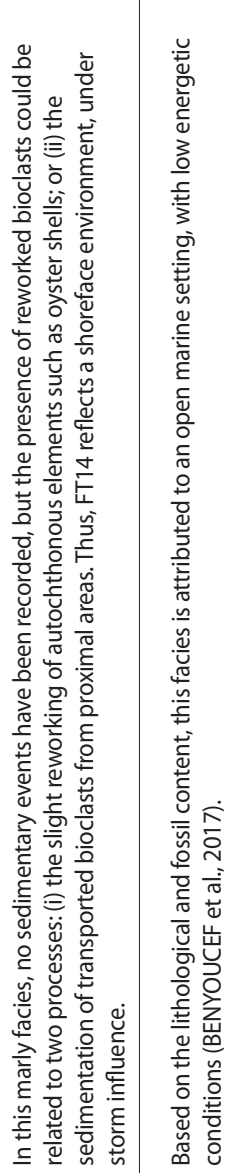

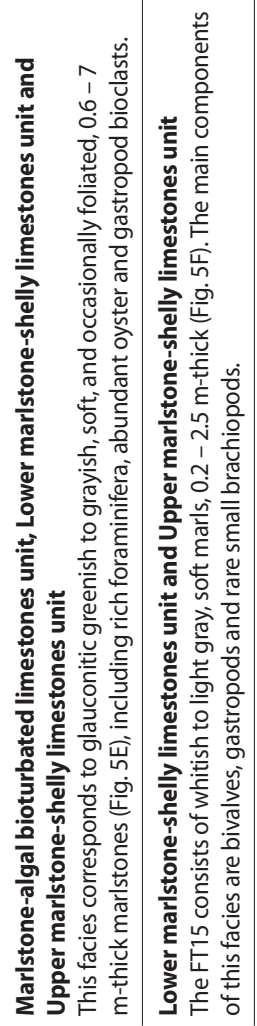

mi

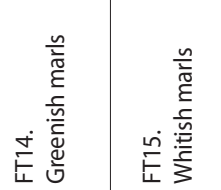


delgadoi (Fig. 3F). The studied specimens are considered to constitute the first record from Algeria. This Actaeonellid gastropod is a widespread middle to upper Albian taxon, recorded from Egypt, France, Morocco and Portugal (SOHL \& KOLLMANN, 1985). A. delgadoi occurs in the Dipoloceras (D.) cristatum and Mortoniceras (M.) inflatum Interval Zones (EL QOT, 2018).

In the uppermost part of the second unit, an ammonite-bearing level has been discovered for the first time in this part of Ouled Nail Mounts, including Mortoniceras sp., Pervinquieria sp. and Engonoceras sp. (Fig. G-H). Mortoniceras and Pervinquieria species indicate the upper Albian sensu lato, and co-occur in the M. (Mortoniceras) pricei, M. (Mortoniceras) inflatum and M. (Mortoniceras) fallax Zones (MONOD ET AL., 2000; KENNEDY ET AL., 2008; GALE \& KENNEDY, 2020). On the basis of this association (Acteonella delgadoi, Mortoniceras sp. and Pervinquieria sp.), a part of the mid-Cretaceous post-Continental Intercalaire marine deposits should correspond to the late Albian.

A similar ammonite-bearing bed has been documented in the late Albian of the Frenda-Tiaret Mounts (BOUALEM, 2018), $300 \mathrm{~km}$ to the northwest of the Djebel Azzedine section. The ammonite fauna which yielded this level indicates the M. (Mortoniceras) pricei and M. (Mortoniceras) fallax condensation Zones, named the Mortoniceras event. The same glauconitic ammonitebearing level was recorded in the Hodna (to the east of our study area), including Hysteroceras orbignyi, Pervinquieria perinflata var. crassissima, Scaphites hugardianus, Stoliczkaia dovsedensis st. notha and Turrilites tuberculatum, and indicating a late Albian age (M. (Mortoniceras) inflatum Zone) (KIEKEN, 1974).

Consequently, the maximum flooding surface related to the mid-Cretaceous transgression in northern Algeria (Frenda-Tiaret, Ouled Nail and Hodna basins) is characterized by condensed Mortoniceratinae-beds, which are diachronous, pointing to a late Albian age sensu lato.

\section{INVERTEBRATE TRACE FOSSILS}

The mid-Cretaceous succession of the Djebel Azzeddine section records a low diversity assemblage of trace fossils. Six ichnogenera were recognized with abundant Thalassinoides, common Skolithos, and rare Gyrolithes, Oichnus, Planolites and Tisoa. Except for Thalassinoides and Tisoa, it was impossible to identify specimens in the ichnospecies level.

\subsection{Gyrolithes isp. (Fig. 6A)}

Description: Bioturbation structures described herein consist of vertical, sinistrally or dextrally spiraled burrows, corkscrewshaped, preserved as epichnial. These burrows are smooth and filled by dark and fine sediment in comparison with the host sediment. They are perpendicular to the bedding. Coil diameter is $40-50 \mathrm{~mm}$, and shaft diameteris $5-8 \mathrm{~mm}$.
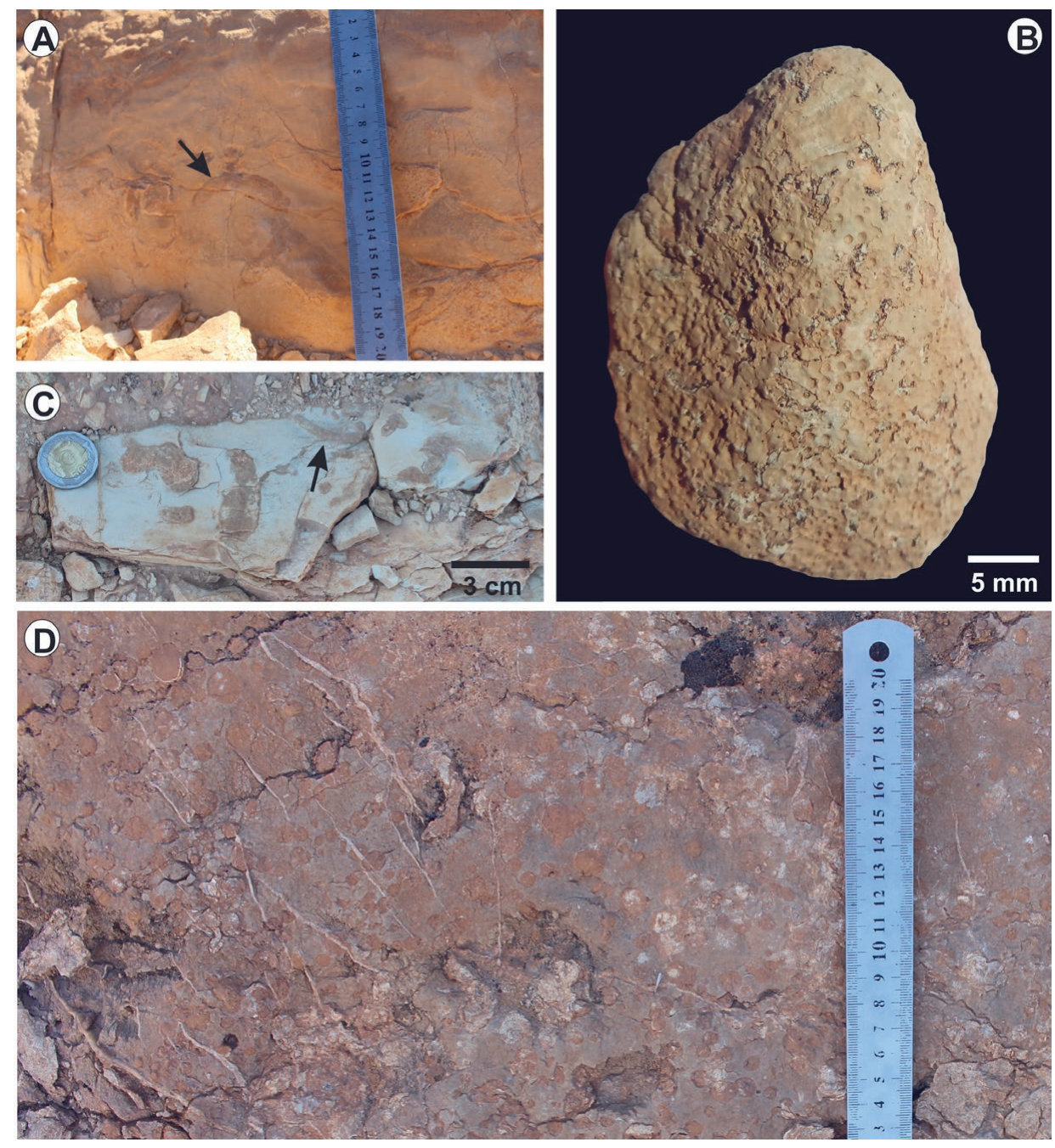

Figure 6. Invertebrate trace fossils from the upper Albian - lower Cenomanian of Ouled Nail Mounts. (A) Gyrolithes isp. (black arrow); (B) Bivalve shell showing abundant Oichnus isp.; (C) Planolites isp. (black arrow) associated with undetermined concretionary burrows; (D) Abundant Skolithos isp. 
Occurrence: Lower marlstone-shelly limestones unit.

Remarks: The ichnogenus Gyrolithes constitutes a domichnion trace fossil produced by crustaceans in intertidal and shallow subtidal environments (GERNANT, 1972; DWORSCHAK \& RODRIGUES, 1997; NETTO et al., 2007). It can also be produced by capitellid polychaetes (POWELL, 1977). Gyrolithes occurs from the Ediacaran - Cambrian boundary (LAING et al., 2018 ) to the Holocene (WETZEL et al., 2010), and indicates a marginal marine environment (GERNANT, 1972; POWELL, 1977; WETZEL et al., 2010). This trace fossil is attributed to the Skolithos and Cruziana ichnofacies (PEMBERTON et al., 2001). Morphological features of the studied burrows resemble that of the ichnospecies G. lorcaensis UCHMAN \& HANKEN (2013) and G. polonicus FEDONKIN (1981).

\subsection{Oichnus isp. (Fig. 6B)}

Description: Circular, sub-circular, oval to weakly elliptical, millimetre-sized borings in the tests of undetermined bivalves. They are perpendicular to the surface of the substrate, and shallower than wide. These borings are over $2 \mathrm{~mm}$ in maximum diameter.

Occurrence: Lower marlstone-shelly limestone unit.

Remarks: Bioerosion structures or borings occur in shallow marine biogenic substrates such as bivalve, brachiopod and echinoid shells (e.g., NAIMI et al., 2021c; VINN et al., 2021a). Many small round holes (or drill holes) in shells are assigned to the ichnogenus Oichnus which is produced essentially by predatory gastropods, particularly naticid gastropods (MÜLLER, 1969), known from the Cambrian (VINN et al., 2021b) to the Holocene (NIELSEN \& NIELSEN, 2001), and belonging to the ichnofamily Oichnidae (WISSHAK et al., 2019). Oichnus is interpreted as an example of Praedichnium (predation traces) with or without signs of attachment (WISSHAK et al., 2015; VALLON et al., 2016).

\subsection{Planolites isp. (Fig. 6C)}

Description: Epichnial burrows preserved in positive epirelief and oriented more or less parallel to the bedding. They consist of simple, unlined, straight, unbranched, slightly inclined burrows, $6 \mathrm{~mm}$ wide and $35 \mathrm{~mm}$ long. Planolites isp. burrows are filled with yellow-red coarser-grained sandy material different from that of the host rock, which is finer and lighter, and co-occur with strong concretionary vertical undetermined burrows characterized by a similar fill.

Occurrence: Upper marlstone-shelly limestones unit.

Remarks: The post-depositional trace fossil Planolitesis interpreted as a feeding trace of vermiform deposit-feeders (UCHMAN, 1995), arthropods and bivalves (KNAUST, 2017). It is considered as a cosmopolitan trace fossil known from the Ediacaran, occurring in different aquatic environments in softgrounds (e.g., UCHMAN, 1995; KNAUST, 2017; BELAID et al., 2020). In a shallow marine setting, Planolites commonly occurs in the Cruziana ichnofacies (BUATOIS \& MÁNGANO, 2011).

\subsection{Skolithos isp. (Fig. 6D)}

Description: Vertical to subvertical, unbranched, cylindrical and tabular burrows, preserved as endichnia. The burrow apertures at the bedding plane surface are circular to slightly oval. Skolithos isp. burrows usually completely penetrate the rock and are filled with a brownish sandy material with small recrystallized bioclasts. They are 2-13 $\mathrm{mm}$ in diameter, with a maximum length of about $120 \mathrm{~mm}$. Skolithos isp. co-occurs with Thalassinoides isp. and dinosaur footprints.
Occurrence: Upper marlstone-shelly limestones unit.

Remarks: The ichnogenus Skolithos characterizes the littoral to shallow sublittoral Skolithos ichnofacies (SEILACHER, 1967). It is created by suspension-feeding organisms such as anthozoans, crustaceans, holothurians, phoronids, polychaetes and priapulids for dwelling (domichnia) (KNAUST, 2017; KNAUST et al., 2018). Skolithos burrows are generally associated with high hydrodynamic energy within shallow water environments (VINN \& WILSON, 2013). This trace fossil is known from the Ediacaran (MCCALL, 2006) through to the Holocene (DASHTGARD \& GINGRAS, 2012).

\subsection{Thalassinoides isp. (Fig. 7A and B)}

Description: Systems of burrows consisting of horizontal tunnels and vertical or inclined cylindrical shafts. Diameters of tunnels and shafts range from 10 to $30 \mathrm{~mm}$. Thalassinoides isp. burrows show Y- and T-shapes, and are filled with a brownish detrital material.

Occurrence: Marlstone-algal bioturbated limestones unit and Lower marlstone-shelly limestones unit.

Remarks: Thalassinoides burrows occur in a shallow marine setting and represent a common constituent of the Cruziana ichnofacies (BENYOUCEF et al., 2012, 2019; CHERIF et al., 2015, 2018; BELAID et al., 2020). They are known from the Ordovician (EKDALE \& BROMLEY, 2003) to the Holocene (NICKELL \& ATKINSON, 1995), and seem to be abundant within Mesozoic and Cenozoic strata (EL-SABBAGH et al., 2017). Thalassinoides is considered as a fodinichnion-domichnion trace fossil produced by decapod crustaceans (FREY et al., 1984). Furthermore, Palaeozoic Thalassinoides may be produced by non-crustacean tracemakers (CARMONA et al., 2004).

\subsection{T. paradoxicus WOODWARD, 1830 (Fig. 7C)}

Description: T. paradoxicus is recorded for the first time from Algeria. It is preserved in positive epichnia and hypichnia, mostly as hypichnia on the sole of the beds. T. paradoxicus is densely branched, subcylindrical to cylindrical burrows, highly irregular in size and morphology. The burrow system is multidirectional and oriented at various angles with respect to bedding, $20-80$ $\mathrm{mm}$ in diameter, occurring as contorted nodules. The tunnels are horizontal, straight to slightly curved, whereas the bifurcations consist mostly of T-shaped intersections than Y-shaped. The burrow filling is similar to that of the host material.

Occurrence: Marlstone-algal bioturbated limestones unit.

Remarks: T. paradoxicus differs from the recorded T. suevicus by its complex irregularly branching system, as well as the predominance of T-branches rather than Y-shaped bifurcations. The studied T. paradoxicus branched system resembles that described in the middle Miocene of Egypt (EL-SABBAGH et al., 2017). It occurs in shallow siliciclastic deposits (KNAUST, 2020), especially in the middle shoreface (HOWARD \& FREY, 1984) to foreshore (CHRZASTEK et al., 2018), and suggests a low energy environment (MÁNGANO \& BUATOIS, 1991). T. paradoxicus burrows are domichnion, documented in firmgrounds characterizing the Glossifungites ichnofacies. They probably required firm, at least semi-consolidated substrates to prevent burrow collapse (MYROW, 1995).

\subsection{T. suevicus RIETH, 1932 (Fig. 7D)}

Description: The studied Thalassinoides suevicus are preserved in epichnia and endichnia, characterized by their complex irreg- 

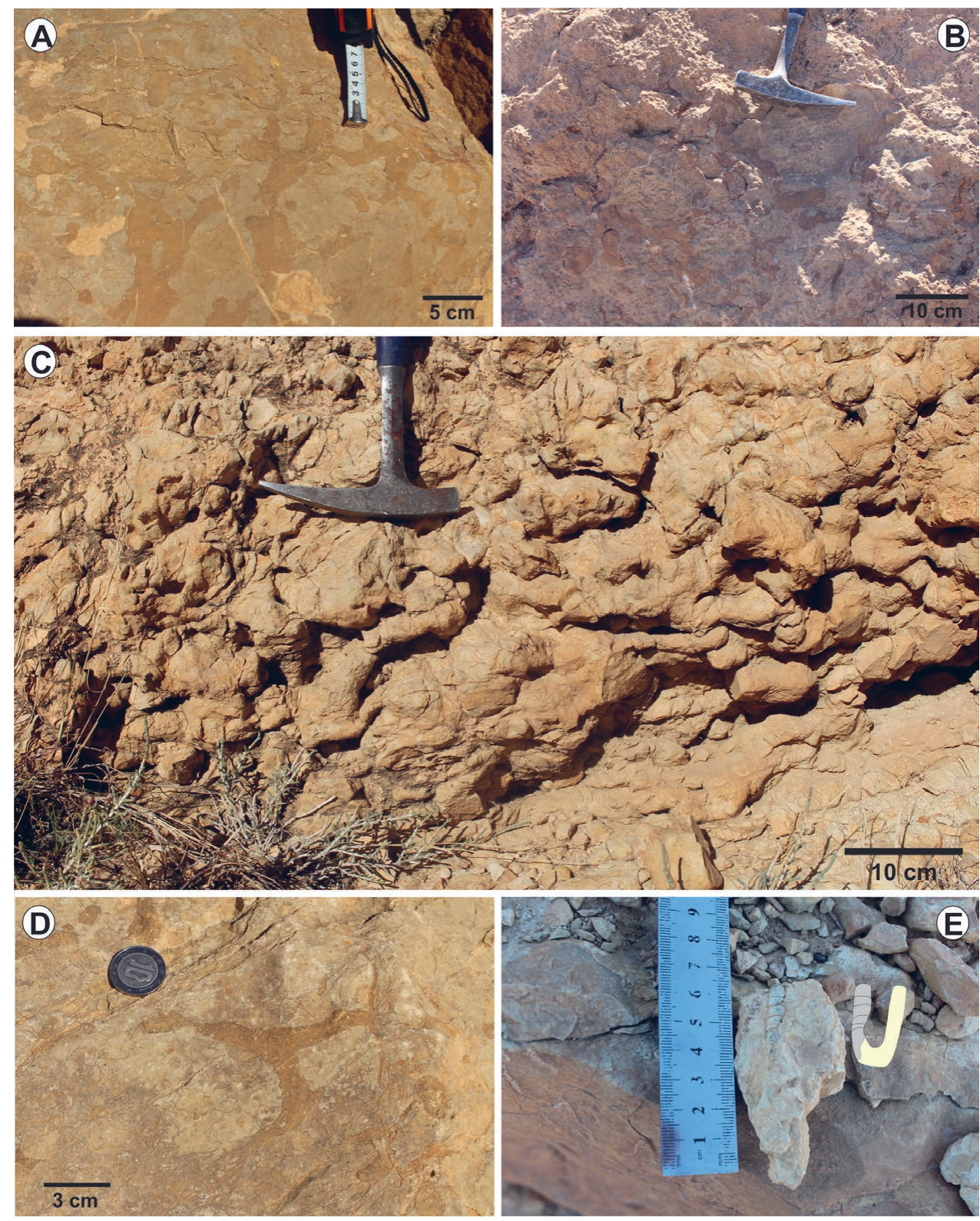

Figure 7. Invertebrate trace fossils from the upper Albian - lower Cenomanian of the Ouled Nail Mounts. (A) Thalassinoides isp. from Unit A; (B) Thalassinoides isp. associated with Skolithos isp. from Unit C; (C) Thalassinoides paradoxicus network; (D) Thalassinoides suevicus; (E) cf. Tisoa siphonalis.

ularly branching system. Tunnels and shaft diameters vary from 5 to $24 \mathrm{~mm}$, filled with a fine brown sandy material. Thereby, dichotomous bifurcations are more common than T-shaped branches.

Occurrence: Marlstone-algal bioturbated limestones unit.

Remarks: Thalassinoides suevicus burrows support a subtidal environment (middle shoreface) (e.g., HOWARD \& FREY, 1984). They characterize the soft grounds (MYROW, 1995), within a shallow marine setting, with well-oxygenated water above the sea floor (NAIMI et al., 2020; NAIMI \& CHERIF, 2021b).

\section{8. cf. Tisoa siphonalis DE SERRES, 1840 (Fig. 7E)}

Description: It consists of a cylindrical, vertical U-shaped burrow, showing laminations within the passive burrow fill, the tube is filled by micritic material. The remaining portion of the wellpreserved tube is $30 \mathrm{~mm}$ long and $6 \mathrm{~mm}$ wide, constituting the long axis of a cylindrical calcareous concretion.
Occurrence: Lower marlstone-shelly limestones unit.

Remarks: The difference between Arenicolites and Tisoa was discussed by KNAUST (2019). Despite the close affinity between these trace fossils, the studied burrow has been attributed to cf. T. siphonalis due to the high length-width ratio and the presence of the calcareous concretion. The studied cf. Tisoa siphonalis resembles the trace fossil Annerepichnites walakhavasensis (sensu KULKARNI \& GHARE, 1991), recorded from shallow marine Bathonian - Kimmeridgian sediments from India, and which has been recently attributed to Tisoa siphonalis (KNAUST, 2019). The key feature of this trace is the presence of a laminated fill, which has been observed in the studied burrow. Tisoa siphonalis occurs in shallow to deep marine environments (KNAUST, 2017, 2019; CHERIF et al., 2021a, b), from the lower Ordovician (PICKERILL \& KEPPIE, 1981) to the Holocene (BADVE \& GHARE, 1984). ++ is interpreted as the result of dwelling activity (domichnion) of polychaetes (KNAUST, 2017), related to widespread authigenic seep carbonate formation (VAN DE 
SCHOOTBRUGGE et al., 2010), and it is common in quasi-anoxic organic-rich and in cold seep deposits (KNAUST, 2019). In Algeria, this ichnospecies has been reported from the lower Miocene Tiaret Marl Formation (CHERIF et al., 2021a) and the early Cretaceous of the Ouarsenis Range (CHERIF et al., 2021b).

\section{DISCUSSION}

\subsection{Ichnological analysis}

The ichnoassemblage of the studied succession is composed of horizontal, vertical and inclined trace fossils constituting an impoverished example of the Skolithos - Glossifungites ichnofacies. It is dominated by domichnion, fodinichnion and praedichnion trace fossils produced mainly by worms, decapods and naticid gastropods.

Trace fossils of the lower part of the section correspond to a firmground suite of the Glossifungites ichnofacies and they are represented essentially by Thalassinoides paradoxicus. The $T$. paradoxicus rich bed (unit A) is characterized by low ichnodiversity, high abundance, and intense bioturbation which destroyed the primary sedimentary structures and the presence of branched burrow systems. These characteristics are typical of the substrate-controlled Glossifungites ichnofacies (BUATOIS \& MÁNGANO, 2011). However, firmground burrowers may produce Tisoa (KNAUST, 2017) and Gyrolithes (NETTO et al., 2007). The typical examples of the Glossifungites ichnofacies (archetypal Glossifungites ichnofacies) are recorded in shallowto marginal marine environments; furthermore, surfaces containing this ichnofacies indicate transgressive events (BUATOIS \& MÁNGANO, 2011). The Glossifungites ichnofacies occurs as a result of intense erosion in the zone of maximum wave energy of wave-dominated tidal flats (YANG et al., 2009).

The Skolithos ichnofacies is well represented in the upper part of the section, mainly dominated by vertical, cylindrical, simple dwelling burrows of suspension-feeders, and characterized by the abundance of three-dimensional burrow systems dominated by vertical components, the absence of horizontal trace fossils produced by a mobile fauna, low ichnodiversity and variable abundance. Skolithos constitutes the most common ichnogenus of the Skolithos ichnofacies, well-known in nearshore settings. The dominance of vertical dwelling structures of infaunal suspension-feeders such as Skolithos isp. indicates the high abundance of organic particles that are kept in suspension in the oxygenated water column by currents and waves (BUATOIS \& MÁNGANO, 2011). The predominance of vertical components over horizontal components indicates relatively high wave energy (HOWARD \& FREY, 1984) related to stressful conditions. Such situations can be indicated by the low ichnodiversity and the monospecific occurrences of Skolithos isp. (MÁNGANO \& BUATOIS, 2004). In shallow marine water, the Skolithos ichnofacies is typical of foreshore to upper- and middle-shoreface environments, and it occurs in lower-intertidal flats depending on the tidal regime (BUATOIS \& MÁNGANO, 2011).

Several dinosaur footprints have been recorded in a similar setting. Marginal marine carbonate sediments of a large innershelf environment, characterized by dolomitic sedimentation related to a warm and dry climate yielded theropod and ornithopod footprints from the Barremian of Portugal (SANTOS et al., 2013). Furthermore, tridactyl footprints which co-occur with bivalves and gastropods have been documented in dolomitic facies from the early Jurassic of France (MOREAU et al., 2018). These tracks are associated with desiccation cracks and they indicate deposi- tion within a periodically emergent environment. The invertebrate trace fossils and mud volcanoes recorded from these deposits allowed attribution of these track-bearing deposits to a subtidal to inter- supratidal flat marsh. In northern Africa, a similar ichnoassemblage including Skolithos and dinosaur footprints (theropod, sauropod and ornithischian), reported torepresent a tidal flat, has been described from the mid-Cretaceous of Morocco (IBRAHIM et al., 2014). Such a vertebrate-invertebrate ichnoassemblage has also been documented in a shallow-marine carbonate setting in the middle Jurassic of Wyoming (KVALE et al., 2001). Invertebrate trace fossils are dominated by vertical and cylindrical burrows attributed to the ichnogenus Skolithos, indicating a soft-ground typical of an intertidal onshore facies persistent during formation of the dinosaur trackway. In the lower Cretaceous of Texas, dinosaur footprints are associated with a shallow invertebrate ichnofauna, suggesting a supratidal to shallow subtidal environment (FARLOW et al., 2012).

\subsection{The mid-Cretaceous transgression and palaeogeography}

The Djebel Azzeddine mid-Cretaceous series could be correlated with the upper unit of the Rhelida Formation, which crops out in the Ksour and Djebel Amour Mounts, respectively in the western and central parts of the Algerian Saharan Atlas. The Rhelida Formation transgressive deposits directly overlay the Continental Intercalaire and have been attributed firstly to the Vraconnian (uppermost Albian) (BASSOULLET, 1973). On the basis of new biostratigraphic data, as well as vertebrate remains from the Rhelida Formation equivalents in Morocco (e.g., CAVIN et al., 2010), Egypt (e.g., LE LOEUFF et al., 2012), and the Guir basin (southwestern Algeria) (BENYOUCEF et al., 2014, 2015, 2016), this Formation has now been dated as lower - middle Cenomanian (BENYOUCEF et al., 2017). Further north of the Saharan Atlas in the Frenda-Tiaret Mounts (northern border of High Plateaus), similar deposits defined as the Mcharref Formation dated as upper Albian (BOUALEM \& BENHAMOU, 2017) overlie the Sidi Ouadah Formation, considered as the equivalent of the Continental Intercalaire (PEYBERNÈS et al., 1986). The condensed ammonite bed [Mortoniceras event sensu BOUALEM (2018)] indicates a maximum flooding surface related to the late Albian transgression (NAGM \& BOUALEM, 2019). Further west, in the Daïa Mounts, the equivalent of the Albian Continental Intercalaire consists of the Grès de Bossuet Formation (AUCLAIR \& BIEHLER, 1967). These fluvio-deltaic sediments are overlain by the late Albian - Cenomanian Djebel Tenfeld carbonate Formation (AUCLAIR \& BIEHLER, 1967; CISZAK, 1993), which yielded new ostracod species (DAMOTTE, 1984). The Albian lower Cenomanian strata of the Tellian Atlas (northwestern Algeria) are represented by turbidite-deposits and deep marl-limestone alternations (e.g., CISZAK, 1993). It is concluded that the mid-Cretaceous transgression is diachronous across northern Algeria. It is precocious (late Albian) in the eastern part of the Saharan Atlas (Ouled Nail basin) and the northern border of the Oran High Plateaus (Daïa and Frenda-Tiaret basins), and more recent in the central and western parts of the Saharan Atlas (Djebel Amour and Ksour basins).

\section{CONCLUSIONS}

New insights on the lithostratigraphy and the palaeoenvironment have been provided from the upper Albian - lower Cenomanian marine succession overlying the Continental Intercalaire in the eastern part of the Ouled Nail Mounts (eastern Algerian Saharan 
Atlas). The studied succession has been subdivided into three distinctive units: The Marlstone-algal bioturbated limestones (unit A), lower marlstone-shelly limestones (Unit B) and upper marlstone-shelly limestones (unit C). Units A and B have been attributed to the upper Albian on the basis of new recorded fossils. A typical Lofer cyclothem with in situ slumped brecciation has been observed from the lowermost part of the section, reflecting local collapses of the carbonate platform. An ammonite-rich bed, discovered at the uppermost part of unit B including mortoniceratids and engonoceratids belonging to Mortoniceras sp., Pervinquieria sp. and Engonoceras sp. has been recorded for the first time in the Bou Saada area. These ammonites indicate a maximum flooding surface of the mid-Cretaceous transgression and could be correlated with similar levels from other Algerian basins such as the Frenda-Tiaret and the Hodna basins. Unit C is barren of any biostratigraphic fauna, but has been assigned to the upper Albian - lower Cenomanian based on its position in the succession.

The studied succession is characterized by a low ichnodiversity containing eight ichnotaxa such as: Gyrolithes isp., Planolites isp., Skolithos isp., Thalassinoides isp., T. paradoxicus, T. suevicus, cf. Tisoa siphonalis, and the boring Oichnus isp. T. paradoxicus and Oichnus isp. are recorded for the first time from Algeria. Thalassinoides burrows are abundant, with common Skolithos, and rare Gyrolithes, Oichnus, Planolites and cf. Tisoa. This ichnoassemblage is dominated by domichnion, fodinichnion and praedichnion trace fossils, and attributed to the Skolithos and Glossifungites ichnofacies.These trace fossils are produced mainly by decapod crustaceans, polychaetes and naticid gastropods. The sedimentological, palaeontological and ichnological data suggest an environment ranging from backshore (supratidal) to shoreface with a mixed (tide/storm) energy source. Also, new small-sized tridactyl dinosaur footprints have been observed in Unit C. Considering the scarcity of diagnostic characters available we refrain from assigning these ichnites to specific ichnotaxa, and more accurate studies are required to proceed in that direction.

\section{ACKNOWLEDGMENT}

We thank the managing editor T. FLUKSI (Zagreb), the associate editor A. MEZGA (Zagreb), M. ANTONELLI (Rome) and an anonymous reviewer for their comments and suggestions which improved this paper. We are especially grateful to D. BERT (Rennes) and W.J. KENNEDY (Oxford) for the identification of the ammonite fauna.

\section{REFERENCES}

AMÉDRO, F. (2008): Support for a Vraconnian Stage between the Albian sensu stricto and the Cenomanian (Cretaceous System).- Carnets de Géologie, 2008/02, 1-83.

AUCLAIR, D. \& BIEHLER, J. (1967): Etude géologique des Hautes Plaines Oranaises entre Tlemcen et Saïda.- Publications du Service de la Carte géologique de l'Algérie, 34, 3-45.

BADVE, R.M. \& GHARE, M.A. (1984): Holocene trace fossils from beach rock of Velas Coast, Raigad District, Maharashtra.- Biovigyanam, 10, 165-172.

BASSOULLET, J.P. (1973): Contribution à l'étude stratigraphique du Mésozoïque de l'Atlas saharien occidental (Algérie). Thèse de Doctorat d'Etat, Université de Paris VI, France, $497 \mathrm{p}$.

BELAID, M., CHERIF, A., VINN, O. \& NAIMI, M.N. (2020): First record of trace fossils from the Oxfordian Argiles rouges de Kheneg Formation (Tiaret, northwestern Algeria).- Geologia Croatica, 73, 85-94.

BENYOUCEF, M., MEISTER, C., BENSALAH, M. \& MALTI, F.Z. (2012): La plateforme préafricaine (Cénomanien supérieur - Turonien inférieur) dans la région de Béchar (Algérie): stratigraphie, paléoenvironnements et signification paléobiogéographiques.- Revue de Paléobiologie, 31, 205-218.
BENYOUCEF, M., ADACI, M., MEISTER, C., LÄNG, E., MALTI, F.Z., MEBARKI, K., CHERIF, A., ZAOUI, D., BENYOUCEF, A. \& BENSALAH, M. (2014): Le «Continental Intercalaire » dans la région du Guir (Algérie): nouvelles données paléontologiques, ichnologiques et sédimentologiques.- Revue de Paléobiologie, 33, 281-297.

BENYOUCEF, M., LÄNG, E., CAVIN, L., MEBARKI, K., ADACI, M. \& BENSALAH, M. (2015): Overabundance of piscivorous dinosaurs (Theropoda: Spinosauridae) in the mid-Cretaceous of North Africa: The Algerian dilemma.- Cretaceous Research, 55, 44-55.

BENYOUCEF, M., MEISTER, C., MEBARKI, K., LÄNG, E., ADACI, M., CAVIN, L., MALTI, F.Z., ZAOUI, D., CHERIF, A. \& BENSALAH, M. (2016): Evolution lithostratigraphique, paléoenvironnementale et séquentielle du Cénomanian-Turonien inférieur dans la région du Guir (Ouest algérien).- Carnets de Géologie, 16, 271-296.

BENYOUCEF, M., MEBARKI, K., FERRÉ, B., ADACI, M., BULOT, L.G., DESMARES, D., VILLIER, L., BENSALAH, M., FRAU, C., IFRIM, C. \& MALTI, F.Z. (2017): Litho- and biostratigraphy, facies patterns and depositional sequences of the Cenomanian-Turonian deposits in the Ksour Mountains (Saharan Atlas, Algeria).- Cretaceous Research, 78, 34-55.

BENYOUCEF, M., ZAOUI, D., ADACI, M., FERRÉ, B., MEISTER, C., PIUZ, A., EL QOT, G.M., MENNAD, A., TCHENAR, S. \& BENSALAH, M. (2019): Stratigraphic and sedimentological framework of the Tinrhert Plateau (CenomanianTuronian, SE Algeria).- Cretaceous Research, 98, 95-121.

BOCKELIE, J.F. (1991): Ichnofabric Mapping and Interpretation of Jurassic Reservoir Rocks of the Norwegian North Sea.- Palaios, 6, 206-215.

BOUALEM, N. (2018): Géométrie de la sédimentation crétacée (Albien-Turonien) des Monts de Tiaret (Frenda, Chellala, Nador...), corrélations et implications paléogéographiques.- Thèse de Doctorat Ès-Sciences, Université d'Oran 2, Algeria, $253 \mathrm{p}$.

BOUALEM, N. \& BENHAMOU, M. (2017): Mise en évidence d'un Albien marin à céphalopodes dans la région de Tiaret (Algérie nord-occidentale) : nouvelles données paléontologiques, implications biostratigraphiques et paléogéographiques.Revue de Paléobiologie, 36, 433-445.

BRANDANO, M., RONCA, S. \& DI BELLA, L. (2020): Erosion of Tortonian phosphatic intervals in upwelling zones: The role of internal waves.- Palaeogeography, Palaeoclimatology, Palaeoecology, 537, 109405.

BROSSARD, E. (1866): Essai sur la constitution physique et géologique des régions méridionales de la subdivision de Sétif (Algérie).- Mémoires du Service Géologique de la France, 2, 177-289.

BUATOIS, L.A. \& MÁNGANO, M.G. (2011): Ichnology: Organism-Substrate Interactions in Space and Time.- Cambridge University Press, $358 \mathrm{p}$.

BUTJOR, L. (2010): Systematics, phylogeny and homeomorphy of the Engonoceratidae Hyatt, 1900 (Ammonoidea, Cretaceous) and revision of Engonoceras duboisi Latil, 1989.- Carnets de Géologie, 2010/08, 1-31.

CAVIN, L., TONG, H., BOUDAD, L., MEISTER, C., PIUZ, A., TABOUELLE, J., AARAB, M., AMIOT, R., BUFFETAUT, E., DYKE, G., HUA, S. \& LE LOEUFF J. (2010): Vertebrate assemblages from the early Late Cretaceous of southeastern Morocco: An overview.- Journal of African Earth Sciences, 57, 391-412.

CHERIF, A., BERT, D., BENHAMOU, M. \& BENYOUCEF, M. (2015): La Formation des Argiles de Saïda (Jurassique supérieur) dans le domaine tlemcenien oriental (Takhemaret, Algérie): données biostratigraphiques, ichnologiques et sédimentologiques.- Revue de Paléobiologie, 34, 363-384.

CHERIF, A., BENYOUCEF, M., FERRÉ, B. \& BENHAMOU, M. (2018): Etude sédimentologique et ichnologique de la Formation des Argiles de Saïda (Jurassique supérieur) dans les monts de Frenda (Algérie nord-occidentale).- Revue de Paléobiologie, 37, 121-135.

CHERIF, A., NAIMI, M.N. \& BELAID, M. (2021a): Deep-sea trace fossils and depositional model from the lower Miocene Tiaret Marl Formation (northwestern Algeria).- Journal of African Earth Sciences, 175, 104115.

CHERIF, A., BENYOUCEF, M., NAIMI, M.N., FERRÉ, B., ZEGHARI, A., FRAU, C. \& BERRABAH, A. (2021b): Trace fossils from the Berriasian-Valanginian of the Ouarsenis Range (northwestern Algeria) and their paleoenvironmental implications.- Journal of African Earth Sciences, 180, 104219.

CHRZĄSTEK, A., MUSZER, J., SOLECKI, A. \& SROKA, A.M. (2018): Rosarichnoides sudeticus igen. et isp. nov. and associated fossils from the Coniacian of the North Sudetic Synclinorium (SW Poland).- Geological Quarterly, 62, 181-196.

CISZAK, R. (1993): Evolution géodynamique de la chaîne tellienne en Oranie (Algérie occidentale) pendant le Paléozoïque et le Mésozoïque.- Strata, 20, 1-513.

DAMOTTE, R. (1984): Ostracodes barrémiens-cénomaniens en Algérie occidentale (coupe du Djebel Cheguiga, Monts de Daïa, Oranie).-Géologie Méditerranéenne, $11,159-172$.

DASHTGARD, S.E. \& GINGRAS, M.K. (2012): Marine Invertebrate Neoichnology.In KNAUST, D. \& BROMLEY, R.G. (eds.): Trace Fossils as Indicators of Sedimentary Environments. Elsevier, 273-295. 
DE SERRES, M. (1840): Description de quelques mollusques fossiles nouveaux des terrains infra-jurassiques et de la craie compacte inférieure du midi de la France.Annales des Sciences Naturelles (Zoologie), 2, 5-25.

DJEBBAR, T. (2000): Structural evolution of the Algerian Saharan Atlas.- PhD thesis, Royal Holloway University of London, United Kingdom, 373 p.

DWORSCHAK, P.C. \& RODRIGUES, S.D.A. (1997): A modern analogue for the trace fossil Gyrolithes: burrows of the thalassinidean shrimp Axianassa australis.- Lethaia, 30, 41-52.

EKDALE, A.A. \& BROMLEY, R.G. (2003): Paleoethologic interpretation of complex Thalassinoides in shallow-marine limestones, Lower Ordovician, Southern Sweden. Palaeogeography, Palaeoclimatology, Palaeoecology, 192, 221-227.

EL QOT, G.M. (2018): Aptian-early Cenomanian ammonites from north Sinai, Egypt: Systematic paleontology and biostratigraphy.-Cretaceous Research, 85, 142-171.

EL-SABBAGH, A., EL-HENEDY, M. \& AL FARRAJ, S. (2017): Thalassinoides in the Middle Miocene succession at Siwa Oasis, northwestern Egypt.- Proceedings of the Geologists' Association, 128, 222-233.

EMBERGER, J. (1960): Esquisse géologique de la partie orientale des Monts des Ouled Naill.- Publications du Service de la Carte géologique de l'Algérie, 27, 1-398.

FARLOW, J.O., O'BRIEN, M., KUBAN, G.J., DATTILO, B.F. \& BATES, K.T. (2012): Dinosaur Tracksites of the Paluxy River Valley (Glen Rose Formation, Lower Cretaceous), Dinosaur Valley State Park, Somervell Country, Texas.- Actas de V Jornadas Internacionales sobre Paleontología de Dinosaurios y suEntorno, Salas de los Infantes, Burgos, 41-69.

FEDONKIN, M.A. (1981): Belomorskaya biota Venda (dokembriyskaiabesskeletnaya fauna severaRusskoyplatformi). Geologicheskiyaei Institute Akademieyya Sciences.- Nauka, Moskva, 342, 1-100.

FERRÉ, B., MEBARKI, K., BENYOUCEF, M., VILLIER, L., BULOT, L.G., DESMARES, D., BENACHOUR, H.B., MARIE, L., SAUVAGNAT, J., BENSALAH, M., ZAOUI, D. \& ADACI, M. (2017): Roveacrinids (Crinoidea, Roveacrinida) from the Cenomanian-Turonian of southwest Algeria (Saharan Atlas and Guir Basin).- Annales de Paléontologie, 103, 185-196

FISCHER, A.G. (1964): The Lofer cyclothems of the Alpine Triassic.- In MERRIAM, D.F. (eds.): Symposium on Cyclic Sedimentation.- Kansas Geological Survey Bulletin, 169, 107-146.

GALE, A.S. \& KENNEDY, W.J. (2020): Upper Albian Ammonites from North-East Texas.- Revue de Paléobiologie, 39, 1-139.

GERNANT, R.E. (1972): The paleoenvironmental significance of Gyrolithes (Lebensspur).- Journal of paleontology, 46, 735-741.

GROSHENY, D., CHIKHI-AOUIMEUR, F., FERRY, S., BENKHEROUF-KECHID, F., JATI, M., ATROPS, F. \& REDJIMI-BOUROUIBA, W. (2008): The Upper Cenomanian-Turonian (Upper Cretaceous) of the Saharan Atlas (Algeria).- Bulletin de la Société géologique de France, 179, 593-603.

GRUN, T.B., KROH, A. \& NEBELSICK, J.H. (2017): Comparative drilling predation on time-averaged phosphatized and nonphosphatized assemblages of the minute clypeasteroid echinoid Echinocyamus stellatus from Miocene offshore sediments (Globigerina Limestone Formation, Malta).- Journal of Paleontology, 91, 633-642.

GUIRAUD, R. (1973): Evolution post-triasique de l'avant-pays de la chaîne alpine en Algérie, d'après l'étude du bassin du Hodna et des régions voisines.- Thèse de Doctorat Ès-Sciences, Université de Nice, France, $270 \mathrm{p}$

HALAMSKI, A.T. \& CHERIF, A. (2017): Oxfordian brachiopods from the Saïda and Frenda mountains (Tlemcenian Domain, north-western Algeria).- Annales Societatis Geologorum Poloniae, 87, 141-156.

HANCOCK, J.M. \& KAUFFMAN, E.G. (1979): The great transgressions of the Late Cretaceous.- Journal of the Geological Society of London, 136, 175-186.

HERKAT, M. (1999): La sédimentation de haut niveau marin du Crétacé supérieur de 1'Atlas saharien oriental et des Aurès. Stratigraphie séquentielle, analyse quantitative des biocénoses, évolution paléogéographique et contexte géodynamique.Thèse de Doctorat, USTHB, Algiers, Algeria, $802 \mathrm{p}$.

HERKAT, M. \& GUIRAUD, R. (2006): The relationships between tectonics and sedimentation in the Late Cretaceous series of the eastern Atlasic Domain (Algeria).Journal of African Earth Sciences, 46, 346-370.

HOWARD, J.D. \& FREY, R.W. (1984): Characteristic trace fossils in nearshore to offshore sequences, Upper Cretaceous of east-central Utah.- Canadian Journal of Earth Sciences, 21, 200-219.

IANNACE, A., FRIJIA, G., CALLUCCIO, L. \& PARENTE, M. (2014): Facies and early dolomitization in Upper Albian shallow-water carbonates of the southern Apennines (Italy): paleotectonic and paleoclimatic implications.- Facies, 60, 169-194.

IBRAHIM, N., VARRICCHIO, D.J., SERENO, P.C., WILSON, J.A., DUTHEIL, D.B., MARTILL, D.M., BAIDDER, L. \& ZOUHRI, S. (2014): Dinosaur Footprints and Other Ichnofauna from the Cretaceous Kem Kem Beds of Morocco. PLoS ONE, 9, e90751

KAZI-TANI, N. (1986): Evolution géodynamique de la bordure nord-africaine: le domaine intraplaque nord-algérien. Approche mégaséquentielle.- Thèse de Doctorat Ès-Sciences, Université de Pau et des Pays de l’Adour, France, 871 p.
KENNEDY, W.J., JAGT, J.W.M., AMÉDRO, F. \& ROBASZYNSKI, F. (2008): The late Albian (Mortoniceras fallax Zone) cephalopod fauna from the Bracquegnies Formation at Strépy-Thieu (Hainaut, Southern Belgium).- Geologica Belgica, 11, $35-69$.

KIEKEN, M. (1974): Etude géologique du Hodna, du Titteri et de la partie occidentale des Biban (Dépt. D’Alger - Algérie).- Publications du Service géologique de l'Algérie, 46, 1-217.

KNAUST, D. (2017): Atlas of Trace Fossils in Well Core: Appearance, Taxonomy and Interpretation. Springer, Dordrecht, $209 \mathrm{p}$.

KNAUST, D. (2019): The enigmatic trace fossil Tisoa de Serres, 1840.- Earth-Science Reviews, 188, 123-147.

KNAUST, D. (2020): The paradoxical ichnotaxonomy of Thalassinoides paradoxicus: a name of different meanings. PalZ, https://doi.org/10.1007/s12542-020-00520-z.

KNAUST, D., THOMAS, R.D.K. \& CURRAN, H.A. (2018): Skolithos linearis Haldeman, 1840 at its early Cambrian type locality, Chickies Rock, Pennsylvania: Analysis and designation of a neotype.- Earth-Science Reviews, 185, 15-31.

KOWALKE, T. \& BANDEL, K. (1996): SystematikundPaläoökologie der Küstenschnecken der nordalpinenBrandenberg-Gosau (Oberconiac/Untersanton) mit einem VergleichzurGastropodenfauna des Maastrichts des Trempbeckens (Südpyrenäen, Spanien). Mitteilungen der BayerischenStaatssammlungfürPaläontologieundhistorischeGeologie, 36, 15-71.

KULKARNI, K.G. \& GHARE, M.A. (1991): Locomotory traces (repichnia) from the Jurassic sequence of Kutch, Gujarat.- Journal of the Geological Society of India, 37, 374-387.

KVALE, E.P., JOHNSON, G.D., MICKELSON, D.L., KELLER, K., FURER, L.C. \& ARCHER, A.W. (2001): Middle Jurassic (Bajocian and Bathonian) Dinosaur Megatracksites, Bighorn Basin, Wyoming, U.S.A.- Palaios, 16, 233-254.

LAING, B.A., BUATOIS, L.A., MÁNGANO, M.G., NARBONNE, G.M. \& GOUGEON, R.C. (2018): Gyrolithes from the Ediacaran-Cambrian boundary section in Fortune Head, Newfoundland, Canada: Exploring the onset of complex burrowing.- Palaeogeography, Palaeoclimatology, Palaeoecology, 495, 171-185.

LE LOEUFF J., LÄNG, E., CAVIN, L. \& BUFFETAUT, E. (2012): Between Tendaguru and Bahariya: on the age of the early cretaceous Dinosaur sites from the continental intercalaire and other African formations.- Journal of Stratigraphy, 36, 1-18.

MÁNGANO, M.G. \& BUATOIS, L.A. (1991): Discontinuity surfaces in the Lower Cretaceous of the High Andes (Mendoza, Argentina): Trace fossils and environmental implications.- Journal of South American Earth Sciences, 4, 215-229.

MÁNGANO, M.G. \& BUATOIS, L.A. (2004): Ichnology of Carboniferous tide-influenced environments and tidal flat variability in the North American Midcontinent.In MCILROY, D. (eds.): The Application of Ichnology to Palaeoenvironmental and Stratigraphic Analysis. Geological Society Special Publication, 228, 157-178.

MARENSSI, S.A., SANTILLANA, S.N. \& RINALDI, C.A. (1998): Stratigraphy of the La Meseta Formation (Eocene), Marambio (Seymour) Island, Antarctica.- Asociación Paleontológica Argentina, Publicación Especial, 5, 137-146.

MCCALL, G.J.H. (2006): The Vendian (Ediacaran) in the geological record: Enigmas in geology's prelude to the Cambrian explosion.- Earth-Science Reviews, 77, $1-229$.

MEBARKI, K., SAUVAGNAT, J., BENYOUCEF, M., ZAOUI, D., BENACHOUR, H.B., ADACI, M., MAHBOUBI, M. \& BENSALAH, M. (2016): Ostracodes cénomano-turoniens dans l'Atlas saharien occidental et le Bassin du Guir (sud-ouest de l'Algérie): systématique, biostratigraphie et paléobiogéographie.- Revue de Paléobiologie, 35, 249-277.

MENNAD, A., TABUCE, R., GUINOT, G., SARR, R., BENYOUCEF, M., BENSALAH, M., CAPPETTA, H., CHARRIÈRE, A. \& ADACI, M. (2020): Découverte d'une nouvelle faune d'âge cénomanien dans la région de Forthassa (Atlas saharien occidental, Algérie): Implications biostratigraphiques et paléoenvironnementales.- Annales de Paléontologie, 106, 102355.

MONOD, O., BUSNARDO, R. \& GUERRERO-SUASTEGUI, M. (2000): LateAlbian ammonites from the carbonate cover of the Teloloapan arc volcanicrocks (Guerrero state, Mexico).- Journal of South American Earth Sciences, 13, 377-388.

MOREAU, J.D., TRINCAL, V., ANDRÉ, D., BARET, L., JACQUET, A. \& WIENIN, M. (2018): Underground dinosaur tracksite inside a karst of southern France: Early Jurassic tridactyl traces from the Dolomitic Formation of the Malaval Cave (Lozère).- International Journal of Speleology, 47, 29-42.

MÜLLER, A.H. (1969): ZurÖkologie und BiostratinomieeinesEchinocorys (Echinoidea) miteigentümlichemNaticiden-Befall aus der Oberkreide.- Monatsberichte der deutschen Akademie der Wissenschaftenzu Berlin, 11, 672-684.

MYROW, P.M. (1995): Thalassinoides and the Enigma of Early Paleozoic Open-Framework Burrow Systems.- Palaios, 10, 58-74.

NAGM, E. \& BOUALEM, B. (2019): First documentation of the late Albian transgression in northwest Algeria: Bivalve stratigraphy and palaeobiogeography.- Cretaceous Research, 93, 197-210.

NAIMI, M.N. \& CHERIF, A. (2021a): Inventory and assessment of significant scientific Algerian geoheritage: Case of remarkable geosites from Orania (Western Algeria).- International Journal of Geoheritage and parks, 9, 13-29. 
NAIMI, M.N. \& CHERIF, A. (2021b): Ichnological analysis of the late Miocene shallow marine diatomaceous deposits of the Lower Chelif basin (northwestern Algeria): paleoenvironmental insights and comparison with deep diatomites.- Journal of African Earth Sciences, 180, 104239.

NAIMI, M.N., MANSOUR, B., CHERIF, A., CHEKKALI, M.C., BENKHEDDA, A. \& BELAID, M. (2020): Lithostratigraphie et paléoenvironnements des dépôts messiniens de la terminaison nord-orientale des monts des Ouled Ali (bassin du Bas Chélif, Algérie nord-occidentale).- Revue de Paléobiologie, 39, 467-483.

NAIMI, M.N., MAHBOUBI, C.Y. \& CHERIF, A. (2021a): Lithostratigraphy and evolution of the Lower Cretaceous Basins, in Western Saharan Atlas, Algeria: A comment.- Journal of African Earth Sciences, 183, 104304.

NAIMI, M.N., VINN, O., CHERIF, A. \& BENYOUCEF, M. (2021b): Trypanites and associated bivalve borings in an Upper Albian hardground from the Eastern Saharan Atlas (Algeria).- Proceedings of the Geologists' Association.

NAIMI, M.N., VINN, O. \& CHERIF, A. (2021c): Bioerosion in Ostrea lamellosa shells from the Messinian of the Tafna basin (NW Algeria).- Carnets de Géologie, 21, $127-135$.

NETTO, R.G., BUATOIS, L.A., MÁNGANO, M.G. \& BALISTIERI, P. (2007): Gyrolithes as a multipurpose burrow: an ethologic approach. Revista Brasileira de Paleontologia, 10, 157-168.

NICKELL, L.A. \& ATKINSON, R.J.A. (1995): Functional morphology of burrows and trophic modes of three thalassinidean shrimp species, and a new approach to the classification of thalassinidean burrow morphology.- Marine Ecology Progress Series, 128, 181-197.

NIELSEN, K.S.S. \& NIELSEN, J.K. (2001): Bioerosion in Pliocene to Late Holocene Tests of Benthic and Planktonic Foraminiferans, with a Revision of the Ichnogenera Oichnus and Tremichnus.- Ichnos, 8, 99-116.

ÖZER, S. \& BENYOUCEF, M. (2021): Late Cenomanian rudists from southern Algeria: descriptions, biostratigraphy, palaeoecology and palaeobiogeography.-Cretaceous Research, 118, 104639.

PEMBERTON, S.G., SPILA, M., PULHAM, A.J., SAUNDERS, T., MACEACHERN, J.A., ROBBINS, D. \& SINCLAIR, I.A. (2001): Ichnology and Sedimentology of Shallow to Marginal Marine Systems: Ben Nevis \& Avalon Reservoirs, Jeanne d'Arc Basin.- Geological Association of Canada Short Course Notes, 15, 1-343.

PÉRON, A. (1883): Essai d'une description géologique de l'Algérie. Editions Masson, Paris, $202 \mathrm{p}$

PEYBERNÈS, B., CISZAK, R. \& CUGNY, P. (1986): La transgression mésocrétacée sur le Haut-Fond de Saïda (avant-pays tellien, Algérie Occidentale).- Bulletin de la Société d'Histoire Naturelle de Toulouse, 122, 51-63.

PICKERILL, R.K. \& KEPPIE, J.D. (1981): Observations on the ichnology of the Meguma Group (? Cambro-Ordovician) of Nova Scotia.- Maritime Sediments and Atlantic Geology, 17, 130-138.

POWELL, E.N. (1977): The relationship of the trace fossil Gyrolithes (= Xenohelix) to the family Capitellidae (Polychaeta).- Journal of Paleontology, 51, 552-556.

RIETH, A. (1932): Neue FundeSpongeliomorpherFucoidenaus dem Jura Schwabens.Geologische und PaläontologischeAbhanlungen, 19, 257-294.

RITTER, E. (1902): Le Djebel Amour et les Monts des Oulad-Nayl. Bulletin du Service de la Carte Géologique de l'Algérie, 2, 1-97.

SALHI, A., ATROPS, F. \& BENHAMOU, M. (2020): Le passage cénomanien-turonien dans les Monts des Ksour (Atlas Saharien Occidental, Algérie): biostratigraphie, géochimie et milieux de depot.- Estudios Geológicos, 76, e135.

SANTOS, V.F., CALLAPEZ, P.M. \& RODRIGUES, N.P.C. (2013): Dinosaur footprints from the Lower Cretaceous of the Algarve Basin (Portugal): New data on the or- nithopod palaeoecology and palaeobiogeography of the Iberian Peninsula.- Cretaceous Research, 40, 158-169.

SCOTESE, C.R. (2013): Map Folio 23, Early Cretaceous (late Albian, 101.8 Ma). PALEOMAP PaleoAtlas for ArcGIS, volume 2, Cretaceous Paleogeographic, Paleoclimatic and Plate Tectonic Reconstructions.- PALEOMAP Project, Evanston, II.

SEILACHER, A. (1967): Bathymetry of trace fossils.- Marine Geology, 5, 413-428.

SHINN, E.A. (1983): Birdseyes, fenestrae, shrinkage pores, and loferites: a reevaluation.- Journal of Sedimentary Petrology, 53, 619-628.

SOHL, N.F. \& KOLLMANN, H.A. (1985): Cretaceous Actaeonellid Gastropods from the Western Hemisphere-- Geological Survey Professional Paper, 1304, 1-104.

STRASSER, A. (1991): Lagoonal-peritidal sequences in carbonate environments: autocyclic and allocyclic processes.- In EINSELE, G., RICKEN, W. \& SEILACHER, A. (eds.): Cycles and Events in Stratigraphy. Springer-Verlag, Berlin, 709-721.

UCHMAN, A. (1995): Taxonomy and palaeoecology of flysch trace fossils: The Marnoso-arenacea Formation and associated facies (Miocene, Northern Apennines, Italy).- Beringeria, 15, 3-115.

UCHMAN, A. \& HANKEN, N.M. (2013): The New Trace Fossil Gyrolithes lorcaensis isp. n. from the Miocene of SE Spain and a Critical Review of the Gyrolithes Ichnospecies.- Stratigraphy and Geological Correlation, 21, 312-322.

VALLON, L.H., RINDSBERG, A.K. \& BROMLEY, R.G. (2016): An updated classification of animal behaviour preserved in substrates.- Geodinamica Acta, 28, 5-20.

VAN DE SCHOOTBRUGGE, B., HARAZIM, D., SORICHTER, K., OSCHMANN, W., FIEBIG, J., PÜTTMANN, W., PEINL, M., ZANELLA, F., TEICHERT, B.M.A., HOFFMANN, J., STADNITSKAIA, A., ROSENTHAL,Y. (2010): The enigmatic ichnofossil Tisoa siphonalis and widespread authigenic seep carbonate formation during the late Pliensbachian in southern France.- Biogeosciences, 7, 3123-3138.

VINN, O. \& WILSON, M.A. (2013): An event bed with abundant Skolithos burrows from the late Pridoli (Silurian) of Saaremaa (Estonia).- Carnets de Géologie, CG2013_L02, 83-87.

VINN, O., NAIMI, M.N. \& CHERIF A. (2021a): The endobiontic serpulids in corals and other reef associated fauna from the Messinian of Algeria.- Neues Jahrbuch für Geologie und Paläontologie, 300, 235-244.

VINN, O., HOLMER, L.E., WILSON, M.A., ISAKAR, M. \& TOOM, U. (2021b): Possible drill holes and pseudoborings in obolid shells from the Cambrian/Ordovician boundary beds of Estonia and the uppermost Cambrian of NW Russia. Historical Biology, in press. https://doi.org/10.1080/08912963.2021.1878355.

WETZEL, A., TJALLINJII, R. \& STATTEGGER, K. (2010): Gyrolithes in Holocene estuarine incised-valley fill deposits, offshore southern Vietnam.- Palaios, 25, 239-246.

WISSHAK, M., KROH, A., BERTLING, M., KNAUST, D., NIELSEN, J.K., JAGT, J.W.M., NEUMANN, C. \& NIELSEN, K.S.S. (2015): In defence of an iconic ichnogenus - Oichnus Bromley, 1981.-Annales Societatis Geologorum Poloniae, 85, $445-451$.

WISSHAK, M., KNAUST, D. \& BERTLING, M. (2019): Bioerosion ichnotaxa: review and annotated list.- Facies, 65, 24.

WOODWARD, S. (1830): A synoptic table of British organic remains, i-xiii.- Longman \& John Stacy, London, 1-50.

YANG, B., DALRYMPLE, R.W., GINGRAS, M.K. \& PERMBERTON, S.G. (2009): Autogenic occurrence of Glossifungites ichnofacies: examples from wave-dominated macrotidal flats, southwestern coast of Korea.- Marine Geology, 260, 1-5. 
